\title{
Social Cohesion and the Anticipated Fall of the Welfare State
}

\author{
Håkan Hydén* \\ Professor in Sociology of Law, Lund University, Sweden
}

Submission: March 12, 2020; Published: May 07, 2020

"Corresponding author: Håkan Hydén, Professor in Sociology of Law, Lund University, Docent in Private Law, Fellow of the World Academy of Arts and Sciences Box 42, SE-22100 LUND, Sweden

Keywords: Social cohesion; Neo-liberal ideologies; Gemeinschaft; Gesellschaft; Community; Society

\section{The Research Problem}

There is a tendency in the whole of Europe to lean more to the right politically with increasing numbers of far-right political parties having neo-liberal ideologies. These events are merely symptoms of the threats and failings of the welfare state model and social cohesion. The state is the present mechanism that is and has been holding European society together. This article will focus on the role that the welfare state model plays in maintaining the social cohesion of western societies and how this system is under an anticipated threat.

We identify certain phenomena which are threatening social cohesion in contemporary society. These threats are namely technological development and migration. Inspired by the theory of anticipation, we claim that these threats are growing and will jeopardize the welfare state model, negatively affecting social cohesion [1]. We will try to draw conclusions of different trends in contemporary society which challenge the social cohesion of the post-industrial societies.

\section{Social Cohesion}

Social cohesion is not a problem for communities with few members. In these cases, society is defined and kept together by interactions between individuals included in the community. Tönnies [2], differentiated between Gemeinschaft and Gesellschaft as social groupings ${ }^{1}$. Gemeinschaft - often translated as community - refers to groupings based on feelings of togetherness and on mutual bonds, which are felt as a goal to be kept up, their members being means for achieving this goal. Gesellschaft - often translated as society - on the other hand, refers to groups that are sustained in order for their members' individual aims and goals to be achieved. Gemeinschaft may be exemplified by a family or a neighborhood in a pre-modern (rural) society; Gesellschaft typically by a jointstock company or non-governmental-organisations. Gesellschaft relationships, Tönnies argued, arose in an urban and capitalist setting, characterized by individualism and impersonal monetary connections between people. Social ties were often instrumental and superficial, with self-interest and exploitation increasingly the norm.

One can here draw parallels with the concepts of primary and secondary groups. A primary group is a typically small social group whose members share close, personal, enduring relationships. These groups are marked by members' concern for one another, and shared activities and culture. This lays the foundation for a normativity which is self-generated and self-reproduced. Examples include family, childhood friends, and highly influential social groups. The concept of the primary group was introduced by Cooley [3]. Although the group initially referred to the first intimate group of a person's childhood, the classification was later extended to include other intimate relations. Primary groups play an important role in the development of personal identity. A primary group is a group in which one exchanges implicit item, such as love, caring, concern, animosity, support, and such. Relationships formed in primary groups are often long-lasting and goals in themselves. They also are often psychologically

${ }^{1}$ My own understanding of societal development in terms of waves is inspired by the expert on future studies, Anders Ewerman, see Ewerman, Anders, Marknaden 1000 år: fem eror i Europa, Ewerman Business Intelligence, Stockholm, 1996 and Ewerman, Anders. 
comforting to the individuals involved and provide a source of support and encouragement.

People in a secondary group interact on a less personal level than in a primary group, and their relationships are temporary rather than long lasting. Since secondary groups are established to perform functions, people's roles are more interchangeable. A secondary group is one you have chosen to be a part of. Therefore, there is a base for a common normativity, which guides the actors' behavior. Secondary groups are based on common interests and activities. Secondary groups are groups in which one exchanges explicit commodities, such as labor for wages, services for payments, and such. Examples of these would be employment, vendor-to-client relationships, and the like. We will approach the problem of social cohesion from a system perspective by regarding the state as a key actor.

A state can be seen as one of these associations, which tries to expand its social control over all of society, both geographically and in terms of social structure [4]. The state is encompassing these other primary and secondary groups. A state is specifically a political and geopolitical entity. It is created in order to decide on and perform collective tasks for individuals and organizations within society and is in that sense on a higher level. A nation is a cultural and ethnic entity. The term "nation state" implies that the two coincide, in that a state has chosen to adopt and endorse a specific cultural group as associated with it. "Nation state" formation can take place at different times in different parts of the world. Migdal inserts an additional distinction between society and state. His thinks it is crucial to make a separation of society and state.

A society can be described as a group of people united by a network of social relations with certain permanence and continuity over time. Societies is territorially demarcated and individuals in the community share common institutions and, to a greater or lesser extent, a common culture and tradition. That is what keeps a society together. A society needs its community members and reproduces itself. It can be more simply described as an economic, social and industrial infrastructure.

A community may be a single ethnic group, such as ethnic Swedes or of a nation, such as Sweden. The more homogeneous a society is in terms of communities and ethnic groups, the more stable it is. Generally, the relationship between state and society is not characterized by domination of one over the other, although this might come to pass in certain circumstances. In both totalitarian regimes $^{2}$ and in welfare states, the state plays a dominant role in holding society together, one with coercive means and the other built on attraction. In fact, both entities influence each other, even where one is weak. The reason for the weakness of these states, for Migdal (1988: 30), lies in the particular structure of their societies.
This leads to the hypothesis that if the structure of society undergoes changes the role of the state also will change. We apply this question to present day challenges and threats faced by the European welfare state system. This requires identifying structural changes in contemporary society and understanding what these structural changes might bring in the future. Before going to tackle these questions, we describe how we understand social cohesion in the present day.

We understand a political system as a one that consists of specialized actors authorized to exert political power. This includes decisions about how the structure of society, laws and public duties. A social system is the patterned series of interrelationships existing between individuals, groups, and institutions and forming a whole. The most typical example of a political system is a state. An economic system can be understood as one that coordinates resources in an organization.

Structure means the organization of the relations between the elements of the system and how these follow different patterns. Social cohesion depends on the way the society succeeds in fulfilling human needs. This means that cohesion depends on how the different systems affect individuals' lives. The organization of society will determine whether society will stay together.

Typical mechanisms for social cohesion would be religion and political ideologies, backed up to a larger or smaller extent by repressive law depending on the legitimacy of the system. The legitimacy is then related to other factors than the ideology, primarily the economic system and how it contributes to the wellbeing of people. This is more or less a general phenomenon when it comes to social cohesion. Another factor of importance for the legitimation of a state is to what extent the leadership is accepted; in connection with trust in society the prevalence of corruption plays a role [5]. Though, it seems that corruption influences the degree of dissatisfaction of the political leadership and the economic system without necessary threatening social cohesion [6].

\section{The Welfare State and Social Cohesion}

We will in this article deal with social cohesion from a western world perspective relating to post-industrialized societies. Sweden is a prominent example [7]. The welfare state is used to describe a state where a social system in which a government is responsible for the economic and social welfare of its citizens and has policies to provide free health care, money for people without jobs, etc. [8]. The political system is based on the premise that the government (and not the individual, corporations, or the local community) has the responsibility for the well-being of its citizens, by ensuring that a minimum standard of living is within everyone's reach. This commitment is translated into provision of universal and free education, universal medical care, insurance

${ }^{2}$ Constantininescu, Emil, A Flat World with Deep Fractures, World Academy of Arts and Sciences, 2016. 
against disability, sickness, and unemployment, family allowances for income supplement, and old age pensions [9]. All these benefits require a high tax system.

The welfare state model provides citizens with material wellbeing, social security, health and education. It is basically a secular model for society where the state apparatus plays a central role for coordination. The production, distribution and consumption of goods and services are taken care of by private companies. Habermas [10] has described the modern society as a combination of systems and lifeworld complementing each other; systems, with the purpose of providing the individuals with material wealth of different kinds and life-world by telling us who we are and what we want.

What Habermas calls systems is following Max Weber. Systems are fully rationalized. The principles of rationalisation are efficiency, calculability, predictability, and control. The point of such rationalisation is to reduce the person to be a part of the "machinery" by which the system does what it does; individual scope of action and decision are minimized: "choices" are strictly limited. By the lifeworld, Habermas means the shared common understandings, including values that develop through face to face contacts over time in various social groups, from families to communities. The lifeworld carries all sorts of assumptions about who we are as people and what we value about ourselves: what we believe, what shocks and offends us, what we aspire to, what we desire, what we are willing to sacrifice to which ends, and so forth.

For Habermas the lifeworld has to be just there, furnishing this sense of who we are and who we value being, but it also requires constant reaffirmation. When we perform the parenthood function, and so forth, we reaffirm to ourselves and each other who we are and what we value. Value-commitments are reaffirmed, and the basis of influence is reestablished. What crucial is that because the lifeworld consists of communicative action-people reaching common understandings on everything from car pools to community action to foreign policy.

Habermas theory is about communicative action. Only communication has the ability to regenerate influence and valuecommitments. The quantitative systems media - economy and politics - money and power, can express influence and valuecommitments, but they cannot generate these qualities-only the communicative action in the life world can do that, according to Habermas. Thus, the crucial point for the legitimacy of the system depends on the lifeworld; it is a one-way direction of the lifeworld making possible the legitimacy of the system. These systems provide norms and imperatives which to a large extent become self-sustained.

Norms are not just a part of normative systems as religion and law, but they also occur in the context of cognitive systems. Norms can be derived from knowledge about a system. It may be the technical knowledge on how to build a house or a bridge. This can include the economic knowledge of how the market looks in a certain respect, etc. It can refer to scientific knowledge about the law of gravity, thermodynamics, photosynthesis, etc. Some of these norms have the character of principles.

In this context the rationality that each system is built around serves as a normative core. Rationality is determined ultimately by the success criteria that each system is built around. What distinguishes the economic system from the social is that norms follow a rationality that is embedded in the system itself. Social systems belong mainly to the life-world, using Habermas' terminology. They are made up of norms that are created when two or more individuals interact with each other by one or other reason. The norms are created by individuals and are dependent on values and aspirations of those involved in the particular case. In the economic system the norms are given by the fundamental principles that characterize the system. The economic system is purpose-driven by its design. It provides on itself, as we have pointed out, the value premises of operators' behavior. The market economy provides incentives and drivers for the players' behavior.

The market economy will benefit certain characteristics of the individuals while - without banning them - are indifferent to other qualities. Since growth is a necessary prerequisite in the capitalist economy, "much" becomes prioritized value compared to "little". If you have decided to play a specific game certain characteristics become exemplary. It is similarly with the capitalist market economy. It rewards certain human characteristics, and ignores other, which has an impact on the direction of what is produced and thus on what is available for consumption in society. The use value for people is subordinated the exchange value in the economic system. GDP reflects the exchange value, which often not correspond to something positive from a human perspective. For instance, as mistrust is growing in society due to increasing crime, the security industry expanding and become one of the biggest and most profitable industries.

Those who act within the framework of an economic system internalize the norms which the specific economic system's success criteria offer. It is this fact that underlies the modernization process which the capitalist market economy has brought along and the uniformity of good and evil runs over the capitalist world today. The market economy works as a kind of framework which, once established gives definite structure to the continuing operations by creating a template for the human activity.

Norms are basic components of what we could call systems of action. Through norms our and others' behavior are synchronized and coordinated and thus forming systems of actions. Norms can be said to be system bound, i.e. formed by the system to which they belong. The political system has its own norms, the economic system like the social system has its norms and the natural, living conditions provided by nature, is subject to its own adherence. Each of these systems has specific conditions and ways of reproducing norms. They play - in varying degrees in form of legislative provisions - a role in the construction and reproduction of society. The construction of society sometimes gives rise to norm conflicts. 
There seems to be a link between inter-system conflicts which are between systems and value conflicts, and between intra-system conflicts within a system and conflicts of interest.

Inter-system conflicts require a value standpoint in relation to incompatible components. This is particularly true when it comes to intersystem conflicts. When one and the same societal activity collide in human practice, conflicts between norms occur. This is the case of wage labor. It is performed by workers and servants of different kind. These can in the wage labor model legitimately from an economic point of view be regarded as commodities which the employer buys to a certain value. At the same time the worker and servant are human beings with their own wishes and needs. This generates social norms which are in contradiction with the economic norms. This structural conflict is what constitutes the conflict between capital and labor in the industrialized societies. The conflict not only shows itself in the labor market. It has also implications for the political system. The modern form of democracy in liberal states is built on the role of balancing the conflict or compensating the workers' lack of economic power with political ditto. In the short term perspective this gives rise to compromises of different kinds in legislation. In the short term perspective this gives rise to compromises of different kinds in legislation. This is reflected in the whole of the labor law and labor market regulation.

Thus, wage labor plays an important role as a principle for the organization of work. With the principles of the organization of work follow a deep impact on society-building, political groups and economic systems. Wage labor is the socio-economic relationship between a worker and an employer, where the worker sells their labor under a formal or informal employment contract. These transactions usually occur in a labor market where wages are market determined [11]. Sweden was in many ways a pioneering country in the sphere of labor relations in the 1950s and 1960s. "The Swedish model" (which can be defined in a number of ways) did, however, change a lot during the late part of the 20th century's ideological stalemates and years of economic difficulties [12].

The Scandinavian countries play a key role in the European social harmonization process. Within the social representation at the European level, there is a sort of informal division of labor, with Denmark serving as the point of reference in terms of employment and Sweden as the model for consideration of different retirement systems. European institutions have almost been infatuated with the development of the Scandinavian model. Typical for Swedish labour market until today, in short, is the following:

a) Approximately $80 \%$ of the labor force is a member of a union. The employers are highly organized, too. This is a necessary condition for the possibility to regulate through collective agreements.

b) The labor market is relatively homogenous.

c) The right to negotiate is very wide and stipulated through law. d) Unions with a collective bargaining agreement are privileged.

e) The collective agreement cannot be stretched to apply to all, it is only binding to the agreeing parties and their members (although they do have "normative effect" and are therefore binding to and for employees who are not a member of a trade union).

f) The right to industrial conflict is very wide and strongly centralized. The individual cannot decide by itself to go on strike. That decision is reserved to the organisations.

g) The regulations are similar between the public and the private sector.

h) There are many regulations benefitting the workers and servants, such as the right to employment protection, to vacation 5 weeks each year, to sick benefits, right to parental leave, etc.

i) There is even a right for the trade union representatives to work with trade union activities during paid working hours.

j) There are very few special regulations for smaller companies.

\section{Anticipated Threats to Social Cohesion}

With Habermas we can conclude that whereas primitive societies are integrated via a basic normative consensus, the integration of developed societies comes about via the systemic interconnection of functionally specified domains of action (Habermas 1981: 115). The differentiation of a highly complex market system destroys traditional forms of solidarity without at the same time producing normative orientations capable of securing an organic form of solidarity (Habermas, 1981: 116). In the case of the life-world, the integration of a system is established by a normatively secured or communicatively achieved consensus, in relation to the systems, by a non-normative regulation of individual decisions that extends beyond the actors' consciousness. This distinction between a social integration of society, which takes effect in action orientations, and a systemic integration, which reaches through and beyond action orientations, calls for a corresponding differentiation in the concept of society itself.

The uncoupling of system integration and social integration means at first only a differentiation between two types of action coordination, one coming about through the consensus of those involved, the other through functional interconnections of action (Habermas, 1981: 186). Social-welfare law and the Welfare state is tailored to domains of action that are first constituted in legal forms of organization and that can be held together only by systemic mechanisms. At the same time, however, socialwelfare law and the welfare state apply to situations embedded in informal lifeworld contexts (Habermas, 1981: 367). With the wage labour model, we can see how the systems de-stabilize and hinder system integration. This creates challenges for the social cohesion of the welfare state. System and life-world come in conflict with each other. However, as long as the systems delivers and provide 
individuals with material wealth, social cohesion seems to uphold.

\section{Technological development as a threat against (welfare) State modelled social cohesion}

The conflict between technology and employment reveals the built-in contradiction between wage labor as a form of production and social order. Wage labor rationality of production is that it reduces the need for human labor and thus wage labor will sooner or later to abolish itself as a social order. This conflict cannot simply be solved within the framework of wage labor society [13]. If one accepts the use of technology, wage labor disappears. If you do not accept the use of technology loses wage labor the specific productivity that forms the basis for its existence. Thus, we face a dilemma that wage labor cannot indefinitely survive as a social order without technological development, while at the same time this technological development makes wage labor more and more superfluous.

The development of ICT technology threatens more and more the welfare state model, which has been the foundation for social cohesion in the industrial society. This gives society a limited scope of time. Society is like any other system initiated, expands, becomes stabilized and dies before finally withering away to become replaced by another societal model [14]. This cyclical way of looking at societal development occurs in many disciplines. Some of the most influential work is related to Wallerstein [15], and his theory about World Systems. A strong proponent of this perspective within economic theory is Kondratiev (1892-1938). He spoke about cycles of about 60 years between boom and depression. These business cycles are called Kondratiev waves.

According to Wilenius and Kurki (2012), a new wave is on its way for the years 2010 - 20150, the 6th wave, which the authors call a new wave of 40 years of global change [16]. Within history, the so called Annales School has used similar ideas of recurrent events. Among other things they use the concept of "the history of mentalities." By mentality, they meant ideas which were not necessarily conscious ones. They are shared within a collective and they change slowly. Perhaps the most prominent member of the Anneles school. Braudel [17], divided historical time into different rhythms (la longue durée). This expression refers to the analysis of trends as a study of continuities and discontinuities where society was regarded as a totality of economic, social and mental patterns ${ }^{1}$.

It seems as if the world opens up for each, new leap in development, i.e. in the transition from one society system to another, from one wave to the next ${ }^{3}$. In the transition from the handicraft/agrarian society to the industrial society, the differences between city and countryside were evened out. During the handicraft/agrarian society, the city's walls determined the frame within which production and purchasing were allowed to take place. After a while, the space became too constricted and via a technological leap, the transformation of primary energy into secondary energy sources, the gulf between city and countryside widened, the city walls were torn down and the flow of trade was set free. In return, the nation State emerged and, thereby, a larger arena for production and trade. We are presently witnessing the latest leap; the nation state weakens through the new information technology, by which boundaries between countries cease being barriers for the peoples' and companies' domiciles. The digital technique gives rise to new economic ways which open up the world. Today, this technological leap has made it possible for us to tear down the remaining few walls which hinder humans from interaction across national state boarders.

When the industrial society's utility curve begins to descend, the prerequisites for politics radically changes. From having been concerned with distribution, the focus will gradually come to rest with crisis management. The politics will acquire the task of trying to conciliate criticisms emerging from people's negative expectations. Politics will shift from having been distinguished as the art of possibilities to becoming the art of the insufficient. In order to solve an impossible equation, politicians use law to smoothen out social inequalities and calm tensions so that cracks in the market economy - built on the idea of the invisible hand do not become visible. What happens in this transition?

This is when the legal form of intervention prevails [18]. Intervening legal rules become the hallmark of this phase of the development of society. In this phase legislation on environmental protection, consumer protection, employment protection, work life protection, gender rights, etc. were introduced. The time of dramatic change between an old and overly mature industrial society and the current information society which we are presently experiencing can, for the sake of simplicity, be described as a transition society, what some scholars call a postmodern society ${ }^{4}$. Within this society, contradictions appear between the old and the new. Tensions arise between people who live with different conceptions of the world depending on where they have mentally localized themselves.

${ }^{3}$ My own understanding of societal development in terms of waves is inspired by the expert on future studies, Anders Ewerman, see Ewerman, Anders, Marknaden 1000 år: fem eror i Europa, Ewerman Business Intelligence, Stockholm, 1996 and Ewerman, Anders and Constantininescu, Emil, A Flat World with Deep Fractures, World Academy of Arts and Sciences, 2016.

${ }^{4}$ The ambivalence the transition society gives rise to be reflected in social sciences. There are two leading theorists of the postmodern society. One is Jean Baudrillard who believed that modern society was characterized by production, while the postmodern come to be characterized by the simulation and a kind of implosion in the signs and symbols from different media. In today's society, we have therefore lost touch with reality, according to Baudrillard. The second theorist, Jean-Francois Lyotard believes that science hierarchical authority over postmodernism is collapsing in a multiplicity of discourses, and that science is no longer entitled to claim the only legitimate truth. Sociologist Zygmunt Bauman is a sociologist who has addressed postmodern problems in multiple books. See e.g. Bauman, Zygmunt \& Bauman, Lydia. Culture in a liquid modern world [Electronic]., Polity, Cambridge, 2011. 


\section{Annals of Social Sciences \& Management studies}

Every system of society describes a type of wave, where the society is born, grows up, matures, only to reach a culmination, die out and finally decompose, leaving only a trace in peoples' memories. The industrial society reached according to, Castells its culmination in the developed world's industrial countries, the OECD countries, in the beginning of the 1970s.

Since then, productivity has continued to increase up until recent time in which the financial crisis forebodes a recession, but the benefit of the societal system has subsided long ago. The industrial society can no longer grant us more benefits. It is this circumstance which leads to financial crises and unstable situations in the stock market. There are no sane alternatives. Admittedly, the benefits are unevenly distributed, but the injustice is structurally built and can only be solved if we abandon our present system and find a new way to live, produce and distribute goods and services. This development follows a logic which applies to all systems. They reach a certain potential, at which point they even become counterproductive. Monopolies - state and private - which have grown strong during the large scale phase of industrial society produce negative consumer value today instead of providing us with constantly better products for lower prices. The development for the better which takes place during these circumstances is an effect of the giants, although everything is beginning to be challenged by small and medium sized companies which are driven by the aspiration to find new solutions, whilst the established companies struggle to keep old solutions which give them advantages. Another trend is globalization. Globalization complicates the social cohesion process. Co-responsibility entails that everyone should make a concerted contribution to shaping the society in which we live and to which we aspire. It also involves concepts of justice and social sustainability. That poses problems when economic forces no longer buttress the national political system and tend to weaken the state's ability successfully to manage inequalities. At the same time, neoliberal globalization invalidates the national area and territorially defined interests. It focuses instead on individuality, as a universal condition, and gives the logics of the market and competition precedence over all others, particularly the logics of solidarity, co-operation and social justice. In these circumstances the question of what is best for Europeans can no longer be posed without considering the general good, which accordingly broadens the concept of welfare and builds a bridge between territorial justice and universal solidarity [19].

The rule of mercantile logic undermines the foundations of social cohesion (or the European social model), destroying one of its essential features - the guarantee of individual and collective rights, for workers and citizens, and fora for consultation and discussion of potential clashes between the logics of competition and citizenship. To ensure that society is capable of guaranteeing the welfare of all its members, social cohesion can, as has been said, adapt and conform to new orders and situations. However, reform of its underlying structures must take account of the historical traditions and principles of citizenship that form the basis of European nations' cultural identity.

How can the collective capacity to ensure everyone's wellbeing be reinforced without a balanced forum for dialogue and consultation founded on an essential political principle such as democratic security? Security is necessary to the development and renewal of social cohesion, to give everyone confidence in the future and make people feel they have a role in shaping their own future and that of coming generations. As the high social and societal cost of job insecurity shows, this form of security must be attainable first and foremost in the employment sphere. However, security is not synonymous with rigidity and barriers to job mobility. It is more a matter of social recognition of a right to transition.

In the past 10 years, global trade in goods and services almost doubled-reaching nearly $\$ 24$ trillion in 2014, up from $\$ 13$ trillion in 2005. The digital components of these flows have also been increasing. By the end of 2015 the planet will have more than 7 billion mobile subscriptions and more than 3 billion Internet users. Sweden and the rest of the industrialized world are in the forefront for this development.

When we talk about technological development we refer primarily to a transition from mechanics to electronics, from analogue to digital technique, the use of nano-technology for different kinds of inventions, etc. This development is not just a technological development as such it lays as a core technological shift the foundation of a new societal model. This development changes the balance between states and companies.

The London based Campaign group, Global Justice Now, has reported figures showing that 69 of the world's 100 most powerful economic entities are companies and not countries (News Voice, 2016). Of the world's 200 top listed economic entities in the world are 153 companies. USA, China, Germany, Japan, France and the UK are the most financially successful, followed by Italy, Brazil and Canada. This situation or trend gives rise to a scary future $^{5}$. The Neo-liberal political economy has accentuated great benefits for the top $1 \%$ of the population with very little trickle down of benefits for the vast majority of citizens in a worldwide perspective. Power elite has never been stronger than today. The top ten most successful companies in the world, which includes Apple, Shell and Walmart, today has a combined profit that is

\footnotetext{
${ }^{5}$ Compare the wording of Aisha Dodwell, Global Justice Now: "Imagine a world in which all society's main functions are controlled by profit-making companies. Schools run by multinational companies. Private security companies have replaced police forces and most of the major infrastructure is in the hands of a small plutocratic elite. Justice is assigned shady business courts where only the rich can evade national legal systems. The poor, on the other hand, have no resources available to the elite's power when they chased away from their estates into deeper poverty. This sounds like dystopian science fiction, but it is not. This is close to the reality we live in. The power of the companies has reached a level never before seen in human history, a power that often reduces power of states".
} 


\section{Annals of Social Sciences \& Management studies}

greater than the combined revenues of 180 of the most "poor" countries of the world total of 195 sovereign states. Neo-liberalism stresses an absolutist notion of property and conspires to limit distribution and participation.

It is not only the economic superiority which is a threat for the sovereignty of the states and the ability for the welfare state to operate as a moderator between economy and politics. Technological development is also threat. The ability to collect, process and cross huge amounts of data provides intermediation platforms with a form of power that can challenge states' sovereign powers in many ways. An intermediation platform is for example a search engine which intermediates between people producing knowledge (web pages) and people seeking knowledge. The most well-known platforms of today are some of the richest private corporations in the World, such as Google, Amazon, Facebook and Apple. Other examples include Uber, which offers an Internetbased service (app) for ordering and payment of taxi fares and carpooling trips. Uber was formed in 2009 and 2014, according to the New York Times is valued at SEK 15 billion.

These platforms have access to more data, more skills and more resources than most nation-states and can use them to perform some of the services that were once the prerogative solely for the states. This is particularly striking in probably the most sensitive sovereign domains: defense and security [20]. Intermediation platforms are now powerful political entities and sometimes act like they are political powers that compete with the governments [21]. For example Microsoft is leading a major battle against the US Department of Justice (referens) for access to data stored in Ireland. The intermediation platforms could soon outperform states in providing essential public services, especially in a context of shrinking public budgets.

An illustrative example of how nation-states become subordinated to big corporations is when the European Commission in June 2014 open three in-depth investigations to examine whether decisions by tax authorities in Ireland, The Netherlands and Luxembourg with regard to the corporate income tax to be paid by Apple, Starbucks and Fiat Finance and Trade, respectively, comply with the EU rules on state aid. The European Commission has concluded that Ireland granted undue tax benefits of up to $€ 13$ billion to Apple. This is illegal under EU state aid rules, because it allowed Apple to pay substantially less tax than other businesses.

The EU claims that Ireland must now recover the illegal aid by repaying the tax benefits. The role of EU state aid control is to ensure Member States do not give selected companies a better tax treatment than others, via tax rulings or otherwise. More specifically, profits must be allocated between companies in a corporate group, and between different parts of the same company, in a way that reflects economic reality ${ }^{6}$.

Apple says that the Commission's case is not about how much Apple pays in taxes, it is about which government collects the money. It will have a profound and harmful effect on investment and job creation in Europe. Today we employ nearly 6,000 people across Ireland, says Apple. The vast majority are still in Cork including some of the very first employees - now performing a wide variety of functions as part of Apple's global footprint. Countless multinational companies followed Apple by investing in Cork, and today the local economy is stronger than ever. Both Apple and Ireland will appeal the decision by EU. The outcome will indicate how far the transition has gone in the battle between corporations and nation-states.

\section{Migration as a threat for social cohesion}

It is clear that the European Union recognizes the challenges that it faces in terms of social cohesion (Council of Europe, 2005). It is thus necessary to expand on the issues raised in the report and extending the issues, not least in light of the large migrant inflows into the EU in recent years and the modern technological developments. Social cohesion requires market forces and administrative rules, and trends therein, to be subject to democratic supervision. However, labor flexibility appears to be a response to events beyond national control. The markets are taking on spatial and temporal characteristics different from those of the democratic process, and the administrative authorities struggle to assume their role of guarantor of rights for all (globalization). Even within our modern European societies, social cohesion is still largely defined in relation to the national area that delimits the dual sense of identity - that of the nation and that of the citizen - on which it is based.

National welfare states are by their nature meant to be closed systems [22]. The logic of the welfare state implies the existence of boundaries that distinguish those who are members of a community from those who are not. Yet the welfare state is necessarily at least partially open to its external environment. International trade, the mobility of capital, and especially the migration of labor continuously intrudes on and challenge the endogenous nature of the welfare state. The development of the welfare state may be seen as dialectical between the distributive logic of closure-mutual aid undertaken by members of a community according to socially defined conceptions of need-and the distributive logic of openness-treatment according to one's performance in the marketplace without regard to membership status or need.

The welfare state requires boundaries because it establishes a principle of distributive justice that departs from the distributive principles of the free market. The principle that-imperfectly governs distribution in the welfare state is that of human

${ }^{6} \mathrm{The}$ EU position is that only the Irish branch of Apple Sales International had the capacity to generate any income from trading, i.e. from the distribution of Apple products. Therefore, the sales profits of Apple Sales International should have been recorded with the Irish branch and taxed there. 
need. It does not replace the market principle of distribution according to economic performance, but it significantly alters it by establishing a social minimum and broadening the sphere of collective consumption, while it at the same time supports the necessary circulation of goods in the capitalistic economy and thereby nurtures the market from an economic perspective. The introduction of the Welfare state model is thus not only a question of political charity or distribution policy. It is also built on strong economic incentives.

The welfare state is an inward looking system. This is due in large part to the community sharing social goods on the basis of social ties, bonds values of kinship. The people who decide in the sharing do so based on need. They have to understand feelings of solidarity and closeness that come from collective membership of fellow human communities ${ }^{7}$. However, the idea of membership suggests that the presence of individual who are non- members are left out of the sharing process. This is what is exploited by the far-right political parties in Europe; Sweden for Swedes and the like. The far-right Finnish party calls itself for the True Finns.

The fundamental political problem in a closed system is determining membership. Being a member implies on is a citizen. The claiming of welfare state benefits thus creates problems for non-members or migrants. Leaving them out of the system is at odds with ideas solidarity and kinship. However, these migrants are not citizens or members of the system. Including them causes friction and separates people into groupings of citizens and noncitizens. Welfare states in order to survive thus encourage an inflow of resources and seek to prevent their outflow. The welfare state is thus an extension of forms of protectionist policies from mercantilist era long gone [23].

These are not the only challenges of the inward looking focus of welfare states. As they are found in a disordered, perilous, and competitive world of limited means, they have to strive to draw resources to come into their borders and fight to prevent their loss. Government-provided social protection measures initially appeared in countries that followed pure mercantilist ideology and policies. The same thinking that was behind trade controls and barriers protectionist tools set up to maintain and grow countries' wealth push the measures to shield national populations from the disturbances to their living standards driven by global business cycles. With this in mind, the welfare state could be viewed as the application of protectionism by other methods. The welfare State, is thus a closed system. It looks to protect and cater for its own, and its capacity to do that is based on its capacity to build a shelter for its members to block out the outside world. Regrettably, though the welfare state adopts boundedness, and needs it, it is in fact thoroughly connected with the framework of the global sociopolitical and economic system.

The very presence of disparities in benefits amongst member states, inspires migration which in its persistence is a risk to the welfare state. Short term migration is attractive to state policy makers as it reduces the drainage on the nations' budget. The major partners of the state in altering a laissez-faire immigration strategy into a temporary-worker system are local workers. In the absence of legal hindrances on continued residence after losing their employment, migrants would have strong reasons to stay in the country even if they do not have jobs.

In a strict temporary-worker system, jobless benefits are not a problem. Migrants who are retrenched will not have their work permits renewed at expiry. They will have large motives look for other jobs instead of claiming unemployment benefits. In addition, these workers who have challenges getting jobs would simply return to their home countries as they would be out of work. The challenge with the temporary-worker system from the perspective of host country is that it is inclined to break down. Potential migrants dodge its regulatory methods and look for employers who are prepared to help them.

Jobless migrants decide to stay in the expectation of finding work in future or to enjoy the services granted to the unemployed. Some migrants get proper paperwork and become citizens while others stay continually without legal papers. As this short term migration changes long-term stays, the longing to be rejoined with one's family becomes too much. Family immigration reduces the differences between migrants and citizens, and tends to remove the fiscal bonuses that short-term migration brings [23].

Borjas (1999) contends that welfare could impact immigration via a few channels. Firstly, nations with more substantial welfare benefits could draw immigrants who otherwise would have not have been attracted. Secondly, the presence of social security benefits may keep immigrants who would have otherwise gone back to their country of origin. Thus the price of selecting one state over another is minimal. This suggests that immigrants who get welfare benefits are likely to choose, and consequently be grouped in states which provide the greatest social benefits.

National welfare states are inherently inward looking by design. The reasoning behind the welfare state requires that restrictions be placed on those who are not members of the community. In the 21st century, it is impossible to exist outside of the globalized environment and all of the interconnectedness this implies. Thus while the welfare state may be a closed system, it cannot avoid trade ties and movement of capital and labour.

${ }^{7}$ The Social Democrats used to give their welfare policy objectives more luster a label which directly translated should be the home of the people. This has been the "Swedish model", based on a series of social reforms. The basic idea was that Sweden would be a home for all, a welfare state, where the state was responsible for the common people could live in social and economic security. 
Boundaries are necessary for the welfare states' existence and they distribution is determined by human need. This however does not supersede the market economy principle of distribution on the basis of economic performance.

In order for the welfare state to operate optimally, it requires community bonds and kinship ties and the sharing of social goods. Sharing implies an implicit agreement to develop some sort of communal bonds in the areas where individuals reside and socialize. This is what is exploited by the far-right political parties in Europe; Sweden for Swedes and the like. The far-right Finnish party calls itself for the True Finns. The fundamental political problem in a closed system is determining membership. Being a member implies on is a citizen. The claiming of welfare state benefits thus creates problems for non-members or migrants. Leaving them out of the system is at odds with ideas solidarity and kinship. However, these migrants are not citizens or members of the system.

Welfare states, in order to survive thus encourage an inflow of resources and seek to prevent their outflow. The welfare state is thus an extension of forms of protectionist policies from mercantilist era long gone [23]. Studies of migration seem to primarily focus on the effect of migration on the home countries. In relation to receiving countries less are known. Political consequences are however obvious. Migration is a feature of social and economic life across many countries, but the profile of migrant populations varies considerably. In part this is because of the variety of sources of migration. In much of Europe, for example, citizens enjoy extensive rights to free movement. In Australia, Canada and New Zealand, managed labor migration plays an important role. Other sources include family and humanitarian migration. Whatever its source, migration has important impacts on our societies, and these can be controversial. The economic impact of migration is no exception.

Germany held regional elections in three states in 2016 and for political analysts, the major talking point was the success of the far-right, anti-immigration party the Alternative for Germany, known as the AfD. The results have been interpreted as a rebuke of Chancellor Angela Merkel's pro-refugee stance, which has seen over one million migrants enter Germany in a year's time. Merkel's Christian Democrat party lost in two of the three states where the elections were held. The AfD made significant gains in all three states, particularly in Saxony-Anhalt where it finished second with $24 \%$ of the vote. But Germany is not alone. Far-right parties have made significant gains in state and regional elections in Europe since January 2015. The situation is the same for the Scandinavian countries.

From liberal Scandinavia to the southern reaches of the continent in Greece and Italy, far-right parties by their own standards are showing sizeable growth in multiple nations (Business Insider, UK, March 2016). In Denmark, long-standing establishment parties are being squeezed by the emergence of a populist movement fronted by the Danish People's Party (DPP). In the 2015 general election, the party recorded $21 \%$ of the vote to become Denmark's second-largest party. It was the DDP's best performance in its history.

If we take a look at Poland, the hard-right Law and Justice party became the first party to govern alone since the restoration of democracy when it swept to a resounding victory in October's parliamentary elections. The party has since implemented a law allowing it to seize control of the state media broadcasters as well as senior civil service directors. Then there's Slovakia, where in March's election $23 \%$ of first-time voters backed the neo-Nazi People's Party Our Slovakia party (L'SNS). For a long time, the prefix "far" denoted distance between parties aggressively-opposed to immigration and the corridors of power. Now, those gaps are being bridged and in a growing number of states right-wing parties are realistic parties of office. Why is this happening? Public mood across Europe is disgruntled right now and there are conditions for populist groups to attract levels of support that years ago they could only dream of. The mass movement of people from the wartorn Middle East into Europe and the greatest refugee crisis since the Second World War has become the single-most dominant political issue across the continent. Traditional parties from the left and right are facing great challenges. Increasing numbers of people are sick of them and trust in politicians in many states is low. It is within this climate of anger and disenchantment that farright parties have been able to grow. This has also been manifested in the Brexit outcome in UK and the Donald Trump election as US president.

So even if migrants according to a report from OECD Migration Policy Debates, May 2014, contribute significantly to labor-market flexibility, notably in Europe, they give rise to political instability. Migrants accounted for $47 \%$ of the increase in the workforce in the United States and 70\% in Europe over the past ten years and migrants can be said to fill important niches both in fast-growing and declining sectors of the economy. But still, immigration is not regarded as desirable. It does not help that according to the same source, migrants contribute more in taxes and social contributions than they receive in benefits and migrants arrive with skills and contribute to human capital development of receiving countries. Migrants also contribute to technological progress. Still there is a huge resistance against migration among ordinary people.

These circumstances lead to a threat for social cohesion. It has been met with different strategies from the state and the political system [24]. These strategies will probably not prevent immigrants from making claims to move to Europe in the belief that the Welfare state will stay forever. This becomes a vicious circle, the more immigration, the more the Welfare state will have problem to fulfil its function as a guarantee for individuals' wellbeing. We have already seen a gradually cut in welfare and social rights all over Europe [25,26]. 


\section{Anticipation of Given Trends}

It is impossible to avoid the consequences of understanding the society without generating concerns for the anticipated future of those social phenomena (Nagan 2016). Indeed, in order to anticipate a projected public and legal order encounters the prospect that description and analysis without a concern for contingent futures misses the point of understanding society and it's anticipated future. Every form of society is holds the view that it will last forever. The historical process of change is recognized in principle in the past, but not for the future, not so far as concerns its own form of society. The established structures of a particular form of society cannot think of change as anything other than an extension of themselves. The established structures of our form of society are all, in one way or another linked to wage labor. This applies to the state and organizations as well as the leading sciences [13]. Thus, in the dominant perspective the welfare state will be forever. However, if we prolong the anticipated consequences of the contradictions within the welfare state we have brought forward, technological development and immigration, we can anticipate a disruption.

Anticipation is a widespread phenomenon present in and characterizing all types of systems, forcing a re-evaluation of the very idea of science [27]. The present interplay between science and institutions is becoming a major impediment to a further development of science [27]. The traditional, bureaucratic structure adopted by organizations and institutions (e.g. governments) derives from an understanding of systems that precedes the discovery of both complexity and anticipation. Anticipation is not the same as prediction. It is something more complex and sophisticated. Traditional structures work as if problems could be addressed individually and in a piecemeal way, with outputs systematically proportionate to relevant inputs, and without any thorough exploration of possible futures ${ }^{8}$. The discipline of anticipation is in its early stages of development. In this regard, it is not different from any other discipline (or science for that matter).

The discipline of anticipation is - as we understand it - built on two prerequisites, prolongation of trends in society and pattern recognition. The fruitfulness of the method relates to the relevance of the identified tendencies in society. We have argued for technological development in terms of a shift from analogue to digital, from mechanics to electronics, as being one fundamental trend in contemporary society worthwhile to analyze in the perspective of long-term trends. The other trend has to do with migration, which has turned out to be a growing phenomenon in our time. When it comes to pattern recognition, we have been able to connect the technological development to a trend of an emerging new society, which is built on other preconditions than the industrial society and the nation-state. How this new society will look like is too early to say, even with the theory of anticipation. Prolongation of tendencies helps us only to identify pathological tendencies. A new society will in the cyclical development of society, show itself as a reaction on the old one and can therefore currently only be subject to a contra-factual discussion [28].

In the perspective of social cohesion, the welfare state model is as we have seen threatened in two ways. One has to do with technological development as such. That is when the new digital technique creates business models which do not fit into the classical mode of the industrial system of production characterized by large scale industries composed by blue color workers and white color servants organized in trade unions. These have played an important role both within workplaces and as a political force by being connected to the Social Democratic Party.

The decrease of wage labor work in relation to the technological development has had its effect on the labor unions [29]. That part of the welfare state which has to do with the labor law system and trade unions are more and more challenged. There is an increasing misfit between an old regulation model belonging to the industrial mode of production and a new model which is more individualized and flexible. The technological development is also a sign of development from one societal model to another, from the industrial model to an ICT based model. This gives rise to the other threat against the welfare state model.

For the purpose of this article we confine ourselves in relation to anticipation, to the basic function to extrapolate relevant tendencies in society. Even if one cannot predict what will happen in the future, we can extrapolate from what we know about today's society to get a rough picture. If the tendencies belong to contradictory systems within inter-system conflicts, there is reason to believe that the extrapolating will anticipate a crash of the system in case. Thus, both the technological development and the migration flow exhibit dilemmas in the long term perspective, i.e. a situation requiring a choice between equally impossible alternatives. Wage labor cannot indefinitely survive as a social order without technological development, while at the same time this technological development makes wage labor more and more superfluous. In relation to migration, the state is faced with the dilemma of either keeping migration beyond own borders or opening the borders completely and then seek alternative solutions for the support of individuals' wellbeing. Every compromise in between will not be sustainable [30-36].

\section{References}

1. David Runciman (2018) How democracy ends. New York: Basic Books.

2. Ferdinand $T$ (2001) Community and Civil Society In: Jose Harris (Ed.), translated by Jose Harris and Margaret Hollis, Cambridge, Cambridge University Press, USA.

${ }^{8}$ This statement is a part of the call for papers to the conference on Anticipation, Agency and Complexity, 6-8 April 2017, Trento (Italy). 


\section{Annals of Social Sciences \& Management studies}

3. Cooley, Charles H (1983) Social organization: a study of the larger mind. Transaction Books, New Brunswick.

4. Migdal Joel S (2001) State in society [Elektronisk resurs] studying how states and societies transform and constitute one another, Cambridge University Press, Cambridge.

5. Heywood, Paul M (2014) Routledge Handbook of Political Corruption.

6. Rothstein Bo (2013) Quality of Government and Corruption from a European Perspective: A Comparative Study of Good Goverment in European Regions (together with Nicholas Charron and Victor Lapuente). Edward Elgar.

7. Angresano James (2011) French welfare state reform: idealism versus Swedish, New Zealand and Dutch pragmatism. [New ed.], London: Anthem.

8. Rönnmar Mia, Numhauser-Henning Ann (2013) Normative Patterns and Legal Developments in the Social Dimension of the EU [Elektronisk resurs]. Hart Publishing Limited, UK.

9. Goodin Robert E (1988) Reasons for welfare: the political theory of the welfare state. Princeton, N.J: Princeton University Press, USA.

10. Jürgen Habermas (1992) Between Facts and Norms (German: Faktizität und Geltung).

11. Deakin Simon F, Wilkinson Frank (2005) The law of the labour market: industrialization, employment and legal evolution. Oxford: Oxford University Press.

12. Lars M (2007) The Swedish Labour Market Model in a Globalised World.

13. Anna C (1983) Lönearbete som samhällsform och ideologi (Wage Labor as form for society and as an ideology).

14. Vincent B (1998) Kondratiev and the dynamics of economic development: long cycles and industrial growth in historical context New York: St. Martin’s Press, USA.

15. Wallerstein (2004) Immanuel Maurice, World-systems analysis: an introduction. Duke University Press, Durham.

16. Clark Stuart (1999) The Annales school. Vol. 3, Fernand Braudel.

17. Fernand B (1981) Civilization and capitalism: 15th-18th century. Vol. 1 , The structures of everyday life: the limits of the possible, (New edn), Collins, London.

18. Hyden H (2017) Från den nya arbetsrätten till den nya arbetsmarknaden (From the New Labor Law to the New Labor Market), 2017 forecoming on Juristförlaget, Lund.

19. Castells Manuel (1996 - 1999) The Information age: economy, society and culture. Vol. 1- 3. Malden, Mass: Blackwell.

20. Faravelon A, Frenot S, Grumbach S (2016) Chasing data in the Intermediation Era: Economy and Security at Stakes. IEEE Security and Privacy Magazine, Institute of Electrical and Electronics Engineers, Economics of Cybersecurity, Part 2.
21. Demchak CC, Dombrowski P (2011) Rise of a Cyberred Westphalian Age. Strategic Studies Quaterly 5(1): 32-61.

22. Castles FG (2010) The Oxford handbook of the welfare state [Elektronisk resurs]. Oxford: Oxford University Press, UK

23. Freeman GP (1986) Migration and the Political Economy of the Welfare State. Annals of the American Academy of Political and Social Science, Vol. 485, From Foreign Workers to Settlers? Transnational Migration and the Emergence of New Minorities (May, 1986), pp. 51-63.

24. Michael B, Andrew G (2000) Immigration and welfare: challenging the borders of the welfare state. London: Routledge, UK.

25. Pierson Paul (1995) Dismantling the Welfare State? Reagan, Thatcher and the Politics of (1995). Dismantling the Welfare State? [Elektronisk resurs]: Reagan, Thatcher and the Politics of Retrenchment. Cambridge: Cambridge University Press, UK.

26. Anders L (2001) Dismantling the Social Democratic welfare model? has the Swedish welfare state lost its defining characteristics? Scandinavian political studies (24): 171-193.

27. Riel M, Roberto P, Pierre R (2013) The Discipline of Anticipation: Exploring Key Issues, Bellagio Document 4: Working Paper 1.

28. Momic D (2016) Proceedings, International Conference: Technology, Society, Future, Podgorica, Montenegro Academy of Sciences and Arts, 2016.

29. Kjellberg A (2013) Union density and specialist/professional unions in Sweden. (Studies in Social Policy, Industrial Relations, Working Life and Mobility. Research Reports; Vol. 2013:2). Department of Sociology, Lund University. OECD Migration Policy Debates May 2014.

30. Giuliano B, David N (2012) The politics of the new welfare state. Oxford: Oxford University Press, UK.

31. Emil C (2016) A Flat World with Deep Fractures. World Academy of Arts and Sciences.

32. Markus CML (2008) Trust beyond borders: immigration, the welfare state, and identity in modern societies. Ann Arbor: Univ. of Michigan Press, USA.

33. Erikson R, et al. (eds.) Welfare Research and Welfare Societies: The Scandinavian Model, M.E. Sharpe.

34. Esping-Andersen G, Korpi W (1987) From Poor Relief to Institutional Welfare States.

35. Håkan H (2014) Towards a Theory of Law and Societal Development, in Scandinavian Studies in Law. In: Peter Wahlgren (Ed.), Vol. 60.

36. Paul P (2001) The new politics of the welfare state. Oxford: Oxford University Press, UK. 
This work is licensed under Creative Commons Attribution 4.0 License

DOI: 10.19080/ASM.2020.05.555658

\begin{tabular}{l} 
Your next submission with Juniper Publishers \\
will reach you the below assets \\
- Quality Editorial service \\
- Swift Peer Review \\
- Reprints availability \\
- E-prints Service \\
- Manuscript Podcast for convenient understanding \\
- Global attainment for your research \\
- Manuscript accessibility in different formats \\
( Pdf, E-pub, Full Text, Audio) \\
- Unceasing customer service \\
Track the below URL for one-step submission \\
https://juniperpublishers.com/online-submission.php \\
\hline
\end{tabular}

